\title{
Direct Screening of a Dynamic Combinatorial Library Using Mass Spectrometry
}

\author{
Sally-Ann Poulsen \\ Eskitis Institute for Cell and Molecular Therapies, Griffith University, Brisbane, Australia
}

\begin{abstract}
A dynamic combinatorial library (DCL) screening approach is described that permits direct identification of the effective (from ineffective) combination of building blocks in the equilibrating DCL. The approach uses Fourier transform ion cyclotron resonance mass spectrometry (FTICR MS) together with sustained off-resonance irradiation collision activated dissociation (SORI-CAD) to detect noncovalent protein-DCL ligand complexes under native conditions. It was shown that in a single, rapid experiment one could concurrently identify all the ligands of interest from the DCL against a background of inactive DCL ligands while still in the presence of the target protein. This result has demonstrated that mass spectrometry may provide a fast preliminary screening approach to identify DCL candidates for later verification with more traditional but time-consuming analysis. The MS/MS enables DCL mixtures to be effectively deconvoluted without the need for either chromatography, synthesis of DCL sub-libraries, conversion of the DCL to a static library, or disruption of the protein-ligand complexes before analysis-all typically necessary for the current screening method for DCLs. (J Am Soc Mass Spectrom 2006, 17, 1074-1080) (c) 2006 American Society for Mass Spectrometry
\end{abstract}

$\mathrm{D}$ ynamic combinatorial chemistry (DCC) has added a new dimension to the synthetic capability of combinatorial chemistry by allowing the combinatorial synthesis to occur through reversible covalent reactions [1-3]. The benefit of this additional dimension becomes readily evident when dynamic combinatorial libraries (DCLs) are prepared in the presence of a therapeutic target molecule. The reversible chemistry, together with the target acting as a template, permits self-screening owing to selection and amplification of the "best binders" by molecular recognition events between DCL constituents and the target. There are now multiple examples of ligand discovery from dynamic combinatorial libraries (DCLs) generated in the presence of protein targets [4-20]. In principle, DCC has the potential to circumvent the need to individually synthesize, characterize, and screen each possible library constituent, however rapid detection of the enriched DCL product(s) still poses a serious analytical problem and is a critical limitation to DCC taking a prominent place in drug discovery [21]. The standard DCL screening approach must carry out the screening of identical DCLs twice-with and without the targetand then compare the equilibrium concentration profiles of all library ligands when generated in both the absence and presence (following disruption of the ligand-target complexes) of target protein $[4,7,10,14-$

Published online June 2, 2006

Address reprint requests to Dr. S.-A. Poulsen, Eskitis Institute for Cell and Molecular Therapies, Griffith University, Nathan, Brisbane 4111, Queensland, Australia. E-mail: s.poulsen@griffith.edu.au
17] - the detection of ligand enrichment in the targeted DCL is the basis of identifying the "best binders". Unfortunately, this screening approach typically necessitates synthesis of individual library components to validate chromatographic (e.g., HPLC) or spectral (e.g., NMR) assignments; this is both labor- and time-intensive and has the effect of undermining the promoted advantages of DCC. The complexity of screening with this indirect method also increases with the size of the DCL owing to chromatographic and/or spectral overlap so that the preparation and screening of DCL sub-libraries becomes necessary for deconvolution of larger DCLs. For DCC to have a significant impact on drug discovery will necessitate the development of a direct screening protocol(s) for rapid identification and characterization of those ligands with affinity for the target protein, against the background of inactive DCL constituents. It would be a tremendous advantage to drug discovery applications of DCC if DCL screening methodologies could proceed without the need for chromatography, prior conversion to a static library, preparation of sub-libraries, prior disruption of the protein-ligand complexes, synthesis of individual library ligands to validate spectral assignments, or for the preparation and duplicate screening of identical DCLs (with and without the target).

The analytical demands of combinatorially generated compound libraries has directed the attention of the pharmaceutical industry towards mass spectrometry owing to attributes of speed, intrinsic sensitivity, specificity, low sample consumption, and capability of resolving vast numbers of compounds in complex com- 


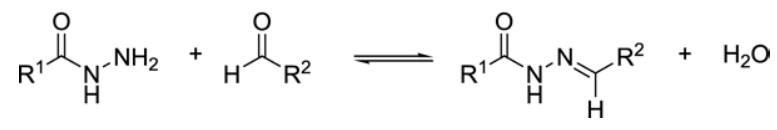

Scheme 1. Reversible hydrazone formation.

pound mixtures [22]. The application of mass spectrometry for studying noncovalent native interactions between proteins and ligands is also well established, and the optimization of experimental parameters to reflect solution composition (and minimize non-specific complexes) has been described [23-35]. On this basis, it was postulated that integration of DCL synthesis with a mass spectrometry based screen could fulfil the screening requirements alluded to above and so provide an alternative means for identifying the most effective combination of building blocks in a DCL with a given target.

The target selected for the current study was the enzyme carbonic anhydrase (CA) (EC 4.2.1.1). Modulation of CAs has been exploited clinically for several decades, however, more recently a role for CA inhibition as an anticancer therapy has been identified owing to a predominance of some CA isoforms in cancer cells and has again created interest in this enzyme as a therapeutic target $[36,37]$. Hydrazone exchange is now one of the most promising reversible reactions for DCC drug discovery applications $[5,6,13,19]$ as it may be performed under reaction conditions that do not disrupt the target proteins function or structure [38, 39], and this reversible reaction was implemented here to generate DCLs targeting CA (Scheme 1). This paper describes the application of electrospray ionization Fourier transform ion cyclotron resonance mass spectrometry (ESI FTICR MS) to the direct screening of a DCL generated by hydrazone exchange against the protein target bovine carbonic anhydrase II (bCA II). The technique combines the attributes of ESI MS described above and, in addition, exploits the capabilities of the FTICR technique to selectively trap, then dissociate these protein-ligand complexes to facilitate DCL ligand identification $[25,26,30]$.

\section{Experimental}

\section{Building Block Design}

Building block 1, a benzene sulfonamide hydrazide, was synthesized as the scaffold building block from which to generate a DCL. Dual functionality was incorporated into the design of $\mathbf{1}$ to provide a scaffold with both reliable bCA II affinity (aromatic sulfonamide) and the capacity to take part in acyl hydrazone exchange (hydrazide moiety). An aromatic sulfonamide moiety
$\left(\mathrm{ArSO}_{2} \mathrm{NH}_{2}\right)$ is the primary recognition element for small molecules to bind the active site of CA [40, 41]. Benzhydrazide (2) lacks the sulfonamide moiety of $\mathbf{1}$, but is still able to participate in hydrazone exchange. Control compound $\mathbf{2}$ was incorporated into the DCL as a means of generating compounds expected to have no affinity for the target bCA II. Five additional building blocks A-E (each containing an aldehyde to act as the hydrazone exchange partners of $\mathbf{1}$ and 2) were also synthesized. Building blocks A-E were derived from amino acids and were selected to introduce "tails" onto 1 to enable exploration of periphery recognition interactions with bCA II that may complement the primary bCA II interaction with the aromatic sulfonamide moiety.

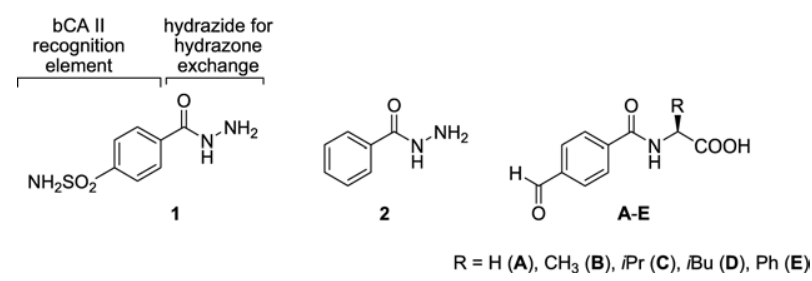

\section{Chemistry}

Building block 2 and all other synthetic reagents used were purchased from Sigma-Aldrich. NMR spectra were recorded at $25^{\circ} \mathrm{C}$ on a Varian Gemini-200 $\left({ }^{1} \mathrm{H} 200\right.$ $\mathrm{MHz},{ }^{13} \mathrm{C} 50 \mathrm{MHz}$ ) NMR spectrometer. The ${ }^{1} \mathrm{H}$ and ${ }^{13} \mathrm{C}$ chemical shifts were referenced to the solvent peak for DMSO- $d_{6}$ or $\mathrm{CDCl}_{3}$ at $\delta_{\mathrm{H}} 2.49$ and $\delta_{\mathrm{C}} 39.5$ or $\delta_{\mathrm{H}} 7.23$ and $\delta_{\mathrm{C}}$ 77.0, respectively. High-resolution mass spectra (HRMS ESI) were recorded on a Bruker Daltonics Apex III 47e FTICR mass spectrometer (Billerica, MA) equipped with an Apollo ESI source. All solvents used for chromatography and MS were Lab-Scan HPLC grade (Dublin, Ireland), and the $\mathrm{H}_{2} \mathrm{O}$ used was Millipore Milli-Q PF filtered (Billerica, MA). Flash chromatography was performed on E. Merck Silica gel GF-60 (Darmstadt, Germany) grade silica (particle size 0.0400$0.063 \mathrm{~mm}$ ). Analytical thin-layer chromatography was performed on 0.25 E Merck silica-gel plates (60-F-254). Analysis of TLC was conducted using standard shortwave $\mathrm{UV}, \mathrm{KMnO}_{4}$ and ninhydrin stains, as appropriate. Reaction yields less than $<1 \mathrm{~g}$ were purified with Varian mega bond elut (Palo Alto, CA) solid-phase extraction columns (normal phase silica). Building block 1 was synthesized from 4-carboxybenzene sulfonamide [42]. Aldehyde building blocks A-E were synthesized in two steps from commercially available amino acid methyl esters.

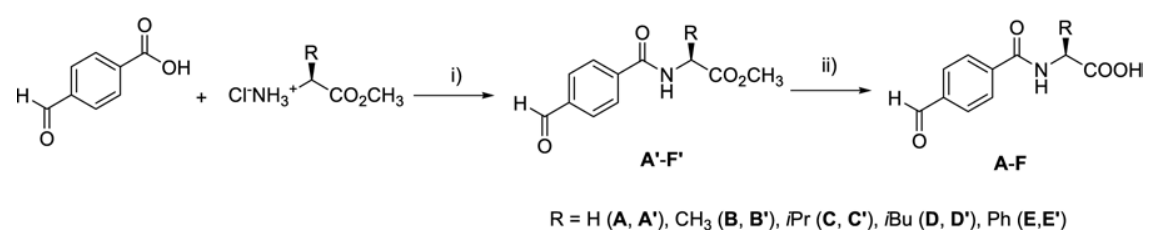


(i) General synthetic method for amide coupling: A solution of 4-carboxybenzaldehyde $(0.5 \mathrm{~g}, 3.3 \mathrm{mmol})$, EDCI (0.64 g, $3.3 \mathrm{mmol})$, and HOBT (0.38 g, $2.83 \mathrm{mmol})$ in $\mathrm{CH}_{2} \mathrm{Cl}_{2}(10 \mathrm{~mL})$ was stirred at room temperature for $20 \mathrm{~min}$. To this activated carboxylic acid solution was added the appropriate L-amino acid methyl ester hydrochloride (3.3 mmol) and one equivalent of diisopropyl ethylamine $(0.575 \mathrm{~mL}, 3.3 \mathrm{mmol})$. The reaction mixture was stirred at room temperature overnight. Workup involved washing with water $(10 \mathrm{~mL}), 2 \mathrm{M}$ $\mathrm{Na}_{2} \mathrm{CO}_{3}(10 \mathrm{~mL})$ and water $(10 \mathrm{~mL})$. The final organic fraction was dried over $\mathrm{MgSO}_{4}$, the solvent removed and the crude material purified by solid-phase extraction on normal-phase silica sorbent using $\mathrm{CH}_{2} \mathrm{Cl}_{2}$ and EtOAc as eluant. The pure chromatography fractions were combined and the solvent removed to afford the amide products as white solids. 2-(4-Formylbenzamido)acetic acid $\mathbf{A}^{\prime}$ (yield 49\%): ${ }^{1} \mathrm{H}$ NMR (200 MHz, DMSO- $\left.d_{6}, \mathrm{ppm}\right): \delta 10.10(\mathrm{~s}, 1 \mathrm{H}, \mathrm{CHO}), 9.21(\mathrm{t}, 1 \mathrm{H}, J=$ $6.0 \mathrm{~Hz}, \mathrm{NH}), 8.05$ (m, 4H, CHarom), 4.06 (d, 2H, $J=6.0$ $\mathrm{Hz}, \mathrm{CH}_{2}$ ), 3.67 (s, 3H, $\mathrm{OCH}_{3}$ ); HRMS (ESI) 222.076554. Calculated for $\mathrm{C}_{11} \mathrm{H}_{12} \mathrm{~N}_{1} \mathrm{O}_{4}^{+}$: 222.076084. (S)-2-(4Formylbenzamido)propanoic acid $\mathbf{B}^{\prime}$ : (yield 50\%): ${ }^{1} \mathrm{H}$ NMR (200 MHz, $\left.\mathrm{CDCl}_{3}, \mathrm{ppm}\right): \delta 10.10$ (s, 1H, CHO), 7.98 (m, 4H, CHarom), 6.89 (d, 1H, J = 7.4 Hz, NH), 4.83 $(\mathrm{m}, 1 \mathrm{H}, \alpha \mathrm{CH}), 3.83\left(\mathrm{~s}, 3 \mathrm{H}, \mathrm{OCH}_{3}\right), 1.56(\mathrm{~d}, 3 \mathrm{H}, \mathrm{J}=6.8$ $\mathrm{Hz}, \mathrm{CH}_{3}$ ); HRMS (ESI) 236.091590. Calculated for $\mathrm{C}_{12} \mathrm{H}_{14} \mathrm{~N}_{1} \mathrm{O}_{4}^{+}$: 236.091734. (S)-2-(4-Formylbenzamido)-3methylbutanoic acid $\mathrm{C}^{\prime}$ : (yield 62\%): ${ }^{1} \mathrm{H}$ NMR (200 MHz, DMSO- $\left.d_{6}, \mathrm{ppm}\right): \delta 10.08(\mathrm{~s}, 1 \mathrm{H}, \mathrm{CHO}), 8.87$ (d, $1 \mathrm{H}, J=8.0 \mathrm{~Hz}, \mathrm{NH}), 8.02$ (s, 4H, CHarom), 4.31 (m, 1H, $\alpha \mathrm{CH}), 3.35\left(\mathrm{~s}, 3 \mathrm{H}, \mathrm{OCH}_{3}\right), 2.18(\mathrm{~m}, 1 \mathrm{H}, \beta \mathrm{CH}), 0.98(\mathrm{~d}$, $\left.3 \mathrm{H}, J=6.8 \mathrm{~Hz}, \gamma \mathrm{CH}_{3}\right), 0.93\left(\mathrm{~d}, 3 \mathrm{H}, J=6.8 \mathrm{~Hz}, \gamma^{\prime} \mathrm{CH}_{3}\right)$; ${ }^{13} \mathrm{C}$ NMR (50 MHz, DMSO- $\left.d_{6}, \mathrm{ppm}\right): \delta 19.7,19.9\left(\gamma \mathrm{CH}_{3}\right.$, $\left.\gamma^{\prime} \mathrm{CH}_{3}\right), 30.3(\beta \mathrm{CH}), 52.4(\alpha \mathrm{CH}), 59.5\left(\mathrm{OCH}_{3}\right), 129.1$, 130.0, 138.6, 139.5 (ArCH), 167.0 (CO), 172.7 (CO), 193.6 (CO); HRMS (ESI) 264.123412. Calculated for $\mathrm{C}_{14} \mathrm{H}_{18} \mathrm{~N}_{1} \mathrm{O}_{4}^{+}$: 264.123034. (S)-2-(4-Formylbenzamido)-4methylpentanoic acid $\mathbf{D}^{\prime}$ : (yield 35\%): ${ }^{1} \mathrm{H}$ NMR (200 $\left.\mathrm{MHz} \mathrm{CDCl}_{3}, \mathrm{ppm}\right): \delta 10.06$ (s, 1H, CHO), 7.93 (s, 4H, CHarom), 6.90 (d, 1H, J = 8.4 Hz, NH), $4.85(\mathrm{~m}, 1 \mathrm{H}$, $\alpha \mathrm{CH}), 3.78\left(\mathrm{~s}, 3 \mathrm{H}, \mathrm{OCH}_{3}\right), 1.63-1.81\left(\mathrm{~m}, 3 \mathrm{H}, \beta \mathrm{CH}_{2}\right.$ and $\gamma \mathrm{CH}), 0.99\left(\mathrm{~m}, 6 \mathrm{H}, \delta \mathrm{CH}_{3}, \delta^{\prime} \mathrm{CH}_{3}\right) ; \mathrm{HRMS}$ (ESI) 278.138804. Calculated for $\mathrm{C}_{15} \mathrm{H}_{20} \mathrm{~N}_{1} \mathrm{O}_{4}^{+}$: 278.138685. (S)2-(4-Formylbenzamido)-3-phenylpropanoic acid $\mathrm{E}^{\prime}$ : (yield 46\%): ${ }^{1} \mathrm{H}$ NMR (200 $\left.\mathrm{MHz} \mathrm{CDCl}_{3}, \mathrm{ppm}\right): \delta 10.09$ (s, 1H, CHO), 7.92 (m, 4H, CHarom), 7.14-7.38 (m, 5H, CHarom), 6.69 (d, 1H, J = $7.4 \mathrm{~Hz}, \mathrm{NH}), 5.13(\mathrm{~m}, 1 \mathrm{H}$, $\alpha \mathrm{CH}), 3.82\left(\mathrm{~s}, 3 \mathrm{H}, \mathrm{OCH}_{3}\right), 3.30\left(\mathrm{~m}, 2 \mathrm{H}, \beta \mathrm{CH}_{2}\right)$; HRMS (ESI) 312.123376. Calculated for $\mathrm{C}_{18} \mathrm{H}_{18} \mathrm{~N}_{1} \mathrm{O}_{4}^{+}$: 312.123034.

(ii) General synthetic method for ester hydrolysis: To a solution of $\mathbf{A}^{\prime}-\mathbf{E}^{\prime}(0.3 \mathrm{mmol})$ in $\mathrm{MeOH}(5 \mathrm{~mL})$ was added $2.5 \mathrm{M} \mathrm{NaOH}(200 \mathrm{~mL})$ and the reaction let to stir at room-temperature overnight after which TLC analysis confirmed complete hydrolysis of the ester. Workup involved removal of $\mathrm{MeOH}$ followed by addition of 2.5 M HCl $(200 \mu \mathrm{L})$. A white precipitate formed and was extracted into $\mathrm{CH}_{2} \mathrm{Cl}_{2}(10 \mathrm{~mL})$. The organic fraction was dried over $\mathrm{MgSO}_{4}$, the solvent removed and the crude material triturated with diethyl ether, affording building blocks A-E as white solids. Methyl 2-(4-formylbenzamido)acetate A (yield 61\%): ${ }^{1} \mathrm{H}$ NMR (200 MHz, $\left.\mathrm{CDCl}_{3}, \mathrm{ppm}\right): \delta 10.12$ (s, 1H, CHO), 8.01 (s, 4H, CHarom), $6.68(\mathrm{~d}, 1 \mathrm{H}, J=5.0 \mathrm{~Hz}, \mathrm{NH}), 4.35(\mathrm{~d}, 2 \mathrm{H}, J=5.0$ $\mathrm{Hz}, \mathrm{CH}_{2}$ ), 1.73 (br s, 1H, OH); HRMS (ESI) 206.045881. Calculated for $\mathrm{C}_{10} \mathrm{H}_{8} \mathrm{~N}_{1} \mathrm{O}_{4}^{-}$: 206.045800. (S)-Methyl 2-(4formylbenzamido)propanoate B: (yield 57\%): ${ }^{1} \mathrm{H}$ NMR (200 MHz, $\left.\mathrm{CDCl}_{3}, \mathrm{ppm}\right): \delta 10.11$ (s, 1H, CHO), 7.99 (s, $4 \mathrm{H}, \mathrm{CHarom}), 6.85$ (d, 1H, J = 7.4 Hz, NH), $4.86(\mathrm{~m}, 1 \mathrm{H}$, $\alpha \mathrm{CH}), 3.39$ (br s, 1H, OH), $1.63\left(\mathrm{~d}, 3 \mathrm{H}, \mathrm{J}=6.6 \mathrm{~Hz}, \mathrm{CH}_{3}\right.$ ); HRMS (ESI) 220.061546. Calculated for $\mathrm{C}_{11} \mathrm{H}_{10} \mathrm{~N}_{1} \mathrm{O}_{4}^{-}$: 220.060899. (S)-Methyl 2-(4-formylbenzamido)-3-methylbutanoate C: (yield 81\%): ${ }^{1} \mathrm{H} \mathrm{NMR}\left(200 \mathrm{MHz}, \mathrm{CDCl}_{3}\right.$, ppm): d 10.12 (s, 1H, CHO), 8.00 (s, 4H, CHarom), 6.70 $(\mathrm{d}, 1 \mathrm{H}, J=7.6 \mathrm{~Hz}, \mathrm{NH}), 4.85(\mathrm{~m}, 1 \mathrm{H}, \alpha \mathrm{CH}), 2.42(\mathrm{~m}, 1 \mathrm{H}$, $\beta \mathrm{CH}), 2.20$ (br s, $1 \mathrm{H}, \mathrm{OH}), 1.10(\mathrm{~d}, 3 \mathrm{H}, J=5.0 \mathrm{~Hz}$, $\left.\gamma \mathrm{CH}_{3}\right), 1.07\left(\mathrm{~d}, 3 \mathrm{H}, J=5.0 \mathrm{~Hz}, \gamma \mathrm{CH}_{3}\right)$; HRMS (ESI) 248.092847. Calculated for $\mathrm{C}_{13} \mathrm{H}_{14} \mathrm{~N}_{1} \mathrm{O}_{4}^{-}$: 248.093721. (S)Methyl 2-(4-formylbenzamido)-4-methylpentanoate D: (yield 79\%): ${ }^{1} \mathrm{H}$ NMR (200 MHz, $\mathrm{CDCl}_{3}, \mathrm{ppm}$ ): d 10.10 (s, 1H, CHO), 7.98 (s, 4H, CHarom), 6.69 (d, 1H, J = 7.6 $\mathrm{Hz}, \mathrm{NH}), 4.89$ (m, 1H, $\alpha \mathrm{CH}), 3.26$ (br s, 1H, OH), 1.83 $\left(\mathrm{m}, 3 \mathrm{H}, \beta \mathrm{CH}_{2}, \gamma \mathrm{CH}\right), 1.03\left(\mathrm{~d}, 6 \mathrm{H}, \mathrm{J}=5.6 \mathrm{~Hz}, \delta \mathrm{CH}_{3}\right.$, $\left.\delta^{\prime} \mathrm{CH}_{3}\right)$; HRMS (ESI) 262.108497. Calculated for $\mathrm{C}_{14} \mathrm{H}_{16} \mathrm{~N}_{1} \mathrm{O}_{4}^{-}$: 262.108791. (S)-Methyl 2-(4-formylbenzamido)-3-phenylpropanoate E: (yield 80\%): ${ }^{1} \mathrm{H}$ NMR (200 MHz, $\mathrm{CDCl}_{3}$, ppm): $\delta 10.10$ (s, 1H, CHO), 7.92 (m, 4H, CHarom), 7.29 (m, 5H, CHarom), $6.66(\mathrm{~d}, 1 \mathrm{H}, \mathrm{J}=7.0$ $\mathrm{Hz}, \mathrm{NH}), 5.14$ (m, 1H, $\alpha \mathrm{CH}), 3.44$ (br s, 1H, OH), 3.34 $\left(\mathrm{m}, 2 \mathrm{H}, \beta \mathrm{CH}_{2}\right.$ ); HRMS (ESI) 296.092848. Calculated for $\mathrm{C}_{17} \mathrm{H}_{14} \mathrm{~N}_{1} \mathrm{O}_{4}^{-}: 296.093392$.

\section{Mass Spectrometry}

The mass spectrometry presented in this paper was performed on an APEX III 4.7 tesla FTICR mass spectrometer (Bruker Daltonics, Billerica, MA) fitted with an Apollo ESI source operated in negative ion mode. XMASS NT V7.0.2 mass spectrometry software on a PC platform was used for data acquisition. Broadband excitation was used to analyze a mass range from $\mathrm{m} / \mathrm{z}$ $100-4500$, with 256,128 , or $32 \mathrm{~K}$ data points acquired. Samples were infused into the ESI source at $2 \mathrm{mLmin}^{-1}$. Nitrogen was used as both the drying gas $\left(125^{\circ} \mathrm{C}\right)$ and nebulizing gas. Relevant parameters include the ESI source pressure $\left(6.2 \times 10^{-7} \mathrm{mbar}\right)$, high vacuum analyzer region pressure $\left(1.3 \times 10^{-10} \mathrm{mbar}\right)$ and hexapole accumulation time of $1 \mathrm{~s}$. MS/MS experiments were performed by sustained off-resonance irradiation collision activated dissociation (SORI-CAD) using argon as the collision gas at an analyzer pressure of $\sim 10^{-8} \mathrm{mbar}$ (argon inlet pressure $2.9 \times 10^{-2} \mathrm{mbar}$ ). The parent ions were selected by use of correlated sweep isolation. The CAD collision energy was tuned to cause dissociation of the noncovalent protein-ligand complexes. Agilent ES tuning mix (catalog number G2421A, Palo Alto, CA) was used for an external four-point calibration. 


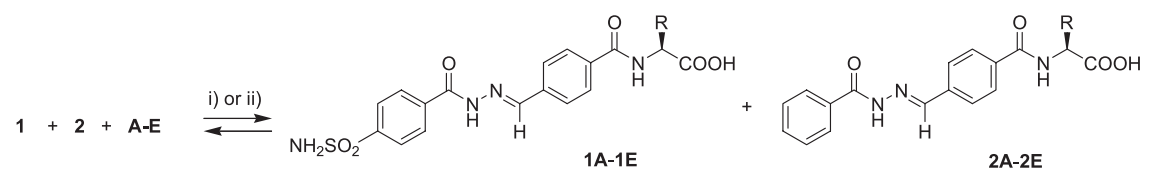

Scheme 2. Generation of a DCL of acyl hydrazones. (i) in situ conditions: bCA II (30 $\mu \mathrm{M}), \mathbf{1}(15 \mu \mathrm{M})$, $2(15 \mu \mathrm{M}), \mathbf{A}-\mathrm{E}\left(6 \mu \mathrm{M}\right.$ each), $10 \mathrm{mM} \mathrm{NH}_{4} \mathrm{OAc}(\mathrm{pH} 7.2), 1 \% \mathrm{DMSO}, 37^{\circ} \mathrm{C}$ for $40 \mathrm{~h}$. (ii) Preformed conditions: $\mathbf{1}(10 \mathrm{mM})$ or $\mathbf{2}(10 \mathrm{mM}), \mathbf{A}-\mathbf{E}\left(2 \mathrm{mM}\right.$ each), DMSO, amberlite resin IRN $120 \mathrm{H}^{+}, \mathrm{pH} \sim 4$, $\mathrm{rt}, 24 \mathrm{~h}$.

\section{Generation of Dynamic Combinatorial Libraries}

CA II from bovine erythrocytes was obtained from Sigma-Aldrich, catalog number C2522, lot number 044K6064. A $30 \mu \mathrm{M}$ solution of bCA II was prepared in $10 \mathrm{mM} \mathrm{NH} \mathrm{NH}_{4} \mathrm{OAc}(\mathrm{pH} 7.2)$, aliquots of the protein solution were either used immediately or stored at $-20^{\circ} \mathrm{C}$. Generation of the in situ DCL of acyl hydrazones 1A-1E and 2A-2E was achieved by incubation of 1,2 , and A-E in the presence of bCA II (conditions (i) of Scheme 2). bCA II $(30 \mu \mathrm{M})$ was mixed with $1(15 \mu \mathrm{M})$, $2(15 \mu \mathrm{M})$, and A-E (6 $\mu \mathrm{M}$ each), with $1 \%$ DMSO to effect solubility, at $37^{\circ} \mathrm{C}$ for $40 \mathrm{~h}$. The total theoretical hydrazone concentration was equivalent to the concentration of bCA II. Preformed hydrazones were generated by the reaction of A-E (2 $\mathrm{mM}$ each), with hydrazides $\mathbf{1}(5 \mathrm{mM})$ and $\mathbf{2}(5 \mathrm{mM})$, respectively, in DMSO as solvent (reaction volume $100 \mu \mathrm{L}$ ) and amberlite resin IRN $120 \mathrm{H}^{+}(5 \mathrm{mg})$ as acid catalyst $(\mathrm{pH} \sim 4)$ (conditions (ii) of Scheme 2). Hydrazone exchange was rapid $(<2 \mathrm{~h})$ as evidenced by loss of ${ }^{1} \mathrm{H}$ NMR signals for the aldehyde protons of A-E (monitored with reactions carried out in DMSO- $\left.d_{6}\right)$. An aliquot of the pre-equilibrated DCL (to give a final hydrazone concentration of $30 \mu \mathrm{M}$ in 1\% DMSO) was then added to an aliquot of bCA II. Both the in situ and pre-equilibrated DCLs were screened using mass spectrometry, the sample quantity consumed for the MS/MS experiment was less than $100 \mu \mathrm{L}$.

\section{Results and Discussion}

\section{Confirmation of Reversibility of Hydrazone Exchange}

Aqueous ammonium acetate is a "volatile buffer" suitable for ESI MS applications to study native proteinligand noncovalent complexes. This buffer ( $\mathrm{pH}$ 7.2) has not before been used for hydrazone exchange and so preliminary for this study was confirmation that hydrazone exchange was indeed dynamic under the condi- tions as used for subsequent MS investigations (hydrazone exchange is rapid at acidic $\mathrm{pH}$ ). Solutions (i) to (iv), each containing a unique hydrazide/aldehyde combination, were prepared in $10 \mathrm{mM} \mathrm{NH}_{4} \mathrm{OAc}, 1 \%$ DMSO (pH 7.2), and incubated at $37^{\circ} \mathrm{C}$ for $40 \mathrm{~h}$. The formation of expected hydrazone products was confirmed by negative ion ESI MS (Table 1). Less than 5\% free hydrazide or aldehyde was detectable.

Solutions (i) and (ii) were then combined (Mix $1=$ 1B, 2E) as were solutions (iii) and (iv) (Mix $2=1 \mathrm{E}, 2 \mathrm{~B}$ ), and incubated (without agitation) at $37^{\circ} \mathrm{C}$ (Scheme 3). The hydrazone composition of both mixes was monitored over time by ESI FTICR MS analysis (Figure 1). Initially, only the original hydrazones were present in solution (Figure 1a), but over time the rearranged hydrazones $\mathbf{1 E}$ and $\mathbf{2 B}$ appeared in Mix 1 and rearranged hydrazones $\mathbf{1 B}$ and $2 \mathrm{E}$ appeared in Mix 2 (Figure $1 \mathrm{~b}-\mathrm{d}$ ). This experiment confirmed that hydrazone exchange was reversible under the neutral conditions used for the native ESI FTICR MS screening.

\section{Screening of DCLs Using Mass Spectrometry}

ESI FTICR MS analysis of bCA II in aqueous ammonium acetate yielded the ESI negative ion mass spectrum of Figure 2a. Peaks corresponding to the $8^{-}$to $10^{-}$ charge states of bCA II were observed, with the $9^{-}$ charge state predominating. This charge state envelope (low charge states and few charge states) is typical for bCA II when in a compact, tightly folded native structure [25-27]. The mass spectrum of the DCL prepared from 1, 2, and A-E in the presence of bCA II (conditions (i) of Scheme 2) is presented in Figure 2b. The same charge state envelope as for bCA II (Figure 2a) was observed, however each charge state now consisted of a grouping of peaks: a peak that corresponded to native bCA II and at higher $m / z$ value a group of peaks that corresponded to bCA II-hydrazone complexes [bCA II-1A-1E] as well as a small amount of [bCA II-1]. The

Table 1. Hydrazone solutions prepared to demonstrate dynamic hydrazone exchange

\begin{tabular}{|c|c|c|c|c|c|}
\hline Solution & Hydrazide $(200 \mu \mathrm{M})$ & Aldehyde $(200 \mu \mathrm{M})$ & Hydrazone product $=[\mathrm{M}]$ & $\begin{array}{c}\text { Molecular weight } \\
\text { calculated for } \\
{[\mathrm{M}-\mathrm{H}]^{-}(\mathrm{Da})}\end{array}$ & $\begin{array}{c}\text { Molecular weight } \\
\text { observed for } \\
{[\mathrm{M}-\mathrm{H}]^{-}(\mathrm{Da})} \\
\end{array}$ \\
\hline (i) & 1 & B & $1 \mathrm{~B}$ & 417.09 & 417.09 \\
\hline (ii) & 2 & E & $2 \mathrm{E}$ & 414.15 & 414.15 \\
\hline (iii) & 1 & E & $1 \mathrm{E}$ & 493.12 & 493.12 \\
\hline (iv) & 2 & B & $2 B$ & 338.11 & 338.11 \\
\hline
\end{tabular}


a)<smiles>CCNC(=O)c1ccc(/C=N/NC(=O)c2ccc(C(=O)NC(Cc3ccccc3)C(=O)O)cc2)cc1</smiles>

b)<smiles>CC(NC(=O)c1ccc(/C=N/NC(=O)c2ccccc2)cc1)C(=O)O</smiles>

Scheme 3. Hydrazone mixes utilized for confirmation of dynamic hydrazone exchange. (a) Mix 1. (b) Mix 2.

mass spectrum obtained with the preformed hydrazones 1A-1E and 2A-2E (generated by acid catalysis before incubation with bCA II, conditions (ii) of Scheme 2) was essentially identical to Figure $2 b$, differing only by the absence of the [bCA II-1] complex. Acid catalyzed hydrazone exchange is extremely rapid and all of the hydrazide scaffold $\mathbf{1}$ is consumed under these

a)
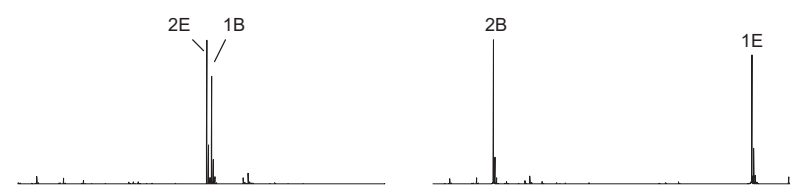

b)
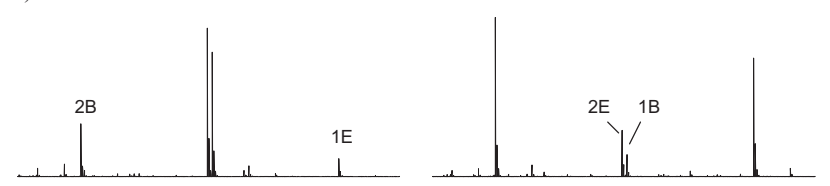

c)

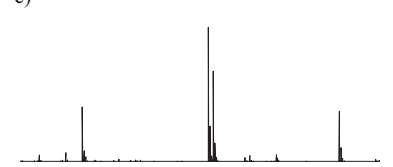

d)
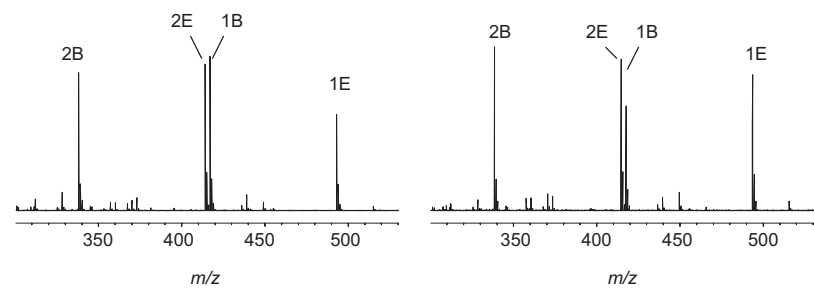

Figure 1. ESI FTICR negative ion mass spectrum of hydrazone Mix 1 (LHS) and hydrazone Mix 2 (RHS). (a) Fifteen min after Mix 1 and Mix 2 were combined. (b) Two days after Mix 1 and Mix 2 were combined. (c) Four days after Mix 1 and Mix 2 were combined. (d) Seven days after Mix 1 and Mix 2 were combined. conditions so that a complex for [bCA II-1] is not observed.

Owing to overlapping isotopic envelopes, a consequence of the size of bCA II $(\sim 29 \mathrm{kDa})$, the [bCA II-hydrazone] complexes were not completely resolved (Figure $2 \mathrm{~b}$ insert) and the MS/MS technique was employed to confirm the identity of the bound ligands from the ten possible hydrazone ligands accessible in

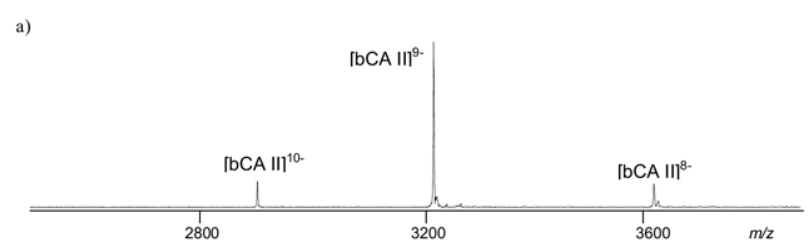

b)
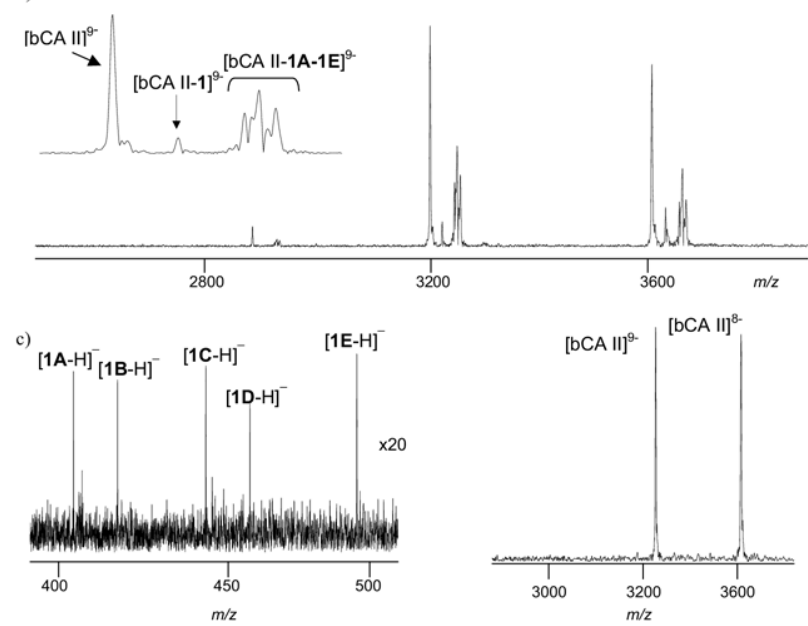

Figure 2. (a) ESI FTICR negative ion mass spectrum of bCA II (30 $\mu \mathrm{M})$ from $10 \mathrm{mM} \mathrm{NH} \mathrm{NH}_{4} \mathrm{OAc}$ solution, 1\% DMSO. (b) ESI FTICR negative ion mass spectrum of a mixture of bCA II $(30 \mu \mathrm{M})$ and DCL containing ten possible hydrazone products in $10 \mathrm{mM}$ $\mathrm{NH}_{4} \mathrm{OAc}$, 1\% DMSO. (c) MS/MS spectrum obtained following collision activated dissociation (CAD) of [bCA II-hydrazone] noncovalent complexes. 
the DCL. Isolation of the ions bearing the $9^{-}$charge state was followed by collision activated dissociation (CAD) resulting in dissociation of the noncovalent complexes (Figure 2c) to yield unbound bCA II, both $8^{-}$ and $9^{-}$charge states, and-important the for application to DCC screening-singly charged negative ions for the hydrazone ligands, now well resolved by molecular mass with $\mathrm{m} / \mathrm{z}$ values between 400 and 500 (Figure 2c). The masses of these ions were consistent with the $[\mathrm{M}-\mathrm{H}]^{-}$ions expected for the DCL sulfonamide hydrazone products 1A-1E (Table 2). No ions in the MS/MS spectrum could be attributed to hydrazones 2A-2E (lacking the sulfonamide moiety). As only hydrazides ( $\mathbf{1}$ and $\mathbf{2}$ ) and aldehydes (A- E) were incubated with the target protein the hydrazones identified from the DCL with affinity for bCA II must have been synthesized in situ by DCC. These results demonstrate that the MS screening approach was able to directly identify ligands of interest from a DCL while in the presence of the target protein without the need for any prior workup.

\section{Validation of Mass Spectrometry Screening Results by a Conventional Enzyme Assay}

A conventional solution phase competitive binding assay [43-45] for bCA II was used to measure the equilibrium dissociation constants (Ki's) for the compounds described in this study. The fluorescence-based assay relies on the competition for the active site of bCAII between the ligand 5-(dimethylamino)-1-napthalenesulphonamide (DNSA) and the test compound [45]. Upon excitation at $290 \mathrm{~nm}$ (an absorption minimum for DNSA) fluorescence is detected at $460 \mathrm{~nm}$ (from the bCAII-DNSA complex). Each of the DCL hydrazones 1A-1E, 2A-2E, as well as building blocks 1 and 2, and aldehydes A-E were individually assessed for their ability to inhibit the binding of DNSA to the active site of bCA II. As expected 2, 2A-2E, and aldehydes A-E (each lacking the sulfonamide moiety) showed no competitive inhibition of DNSA binding even at ligand concentrations up to $100 \mu \mathrm{M}$. The equilibrium dissociation constants (Ki's) measured for sulfonamides $\mathbf{1}$ and 1A-1E are given in Table 3. The DCL products $1 \mathrm{~A}-\mathbf{1 E}$ each exhibited increased affinity for the enzyme (Ki

Table 2. Molecular weights for bCA II bound ligands identified from in situ screening of the DCL by ESI FTICR MS

\begin{tabular}{ccc}
\hline $\begin{array}{c}\text { Molecular weight } \\
\text { observed } \\
{[\mathrm{M}-\mathrm{H}]^{-}(\mathrm{Da})^{\mathrm{a}}}\end{array}$ & Compound $=[\mathrm{M}]$ & $\begin{array}{c}\text { Molecular weight } \\
\text { calculated for } \\
{[\mathrm{M}-\mathrm{H}]^{-}(\mathrm{Da})}\end{array}$ \\
\hline \hline 403.06 & 1A & 403.07 \\
417.07 & 1B & 417.09 \\
445.10 & 1C & 445.12 \\
459.11 & 1D & 459.13 \\
493.09 & 1E & 493.12 \\
\hline
\end{tabular}

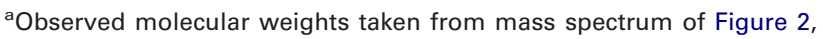
entry c.
Table 3. bCA II competitive binding assay results for 1, 1A-1E, and standard bCA II inhibitors acetazolamide and sulphanilamide expressed as $\mathrm{Ki}$ in $\mathrm{nM}$

\begin{tabular}{lr}
\hline \multicolumn{1}{c}{ Compound } & bCA II Ki $\left(\mathrm{R}^{2}\right)^{\mathrm{a}}$ \\
\hline \hline 1 & $150.0(0.98)$ \\
1A & $65.9(0.97)$ \\
$1 \mathrm{~B}$ & $10.6(0.98)$ \\
$1 \mathrm{C}$ & $69.3(0.97)$ \\
1D & $82.3(0.97)$ \\
1E & $22.5(0.98)$ \\
Acetazolamide & $6.9(0.96)$ \\
Sulfanilamide & $1690(0.97)$ \\
\hline
\end{tabular}

${ }^{a} \mathrm{bCA}$ II binding data utilizing competitive displacement of DNSA from bCA II.

range 10.6-82.3 $\mathrm{nM}$ ) when compared to the scaffold building block $1(\mathrm{Ki}=150 \mathrm{nM})$. These conventional assay results were in complete agreement with bCA II ligand affinity as determined in the mass spectral screen as only those ligands with affinity for bCA II (i.e., 1, 1A-1E) formed noncovalent complexes with bCA II under the native ESI mass spectrum conditions employed. Hydrazone linked sulfonamide-amino acid conjugates represent a new class of potent bCA II inhibitors.

\section{Conclusions}

In conclusion, a single and rapid (minutes) mass spectrometry experiment has permitted concurrent identification of all ligands of interest from a DCL in the presence of the protein target, without the need for any prior workup. This direct approach integrates DCL synthesis with screening and offers an attractive single analysis alternative to the current ligand enrichment screening methodology. The approach readily distinguishes the effective (from ineffective) combination of building blocks in the DCL by detection of specific protein-ligand noncovalent complexes. Comparison with a conventional enzyme assay was fully consistent with the MS result. It is reasonable to expect that increased DCL size need not increase the complexity of this screening protocol, owing to the sensitivity, highresolution, and MS/MS capabilities of the FTICR MS technique, this should avoid the need for multiple sub-libraries to deconvolute larger DCLs. This mass spectrometry screening approach may provide a fast preliminary DCL screen to identify candidates for later verification with more traditional but time-consuming approaches as so may better equip DCC for the screening challenges and demands of modern drug discovery programs.

\section{Acknowledgments}

The author gratefully acknowledges the financial support of this work by the Australian Research Council (grant nos. F00103312, LE237908) and Griffith University. 


\section{References}

1. Lehn, J.-M. Dynamic Combinatorial Chemistry and Virtual Combinatorial Libraries. Chem. Eur. J. 1999, 5, 2455-2463.

2. (a) Rowan, S. J.; Cantrill, S. J.; Cousins, G. R. L.; Sanders, J. K. M.; Stoddart, J. F. Dynamic Covalent Chemistry. Angew. Chem. 2002, 114, 938-993; (b)Angew. Chem. Int. Ed. 2002, 41, 898-952.

3. Cousins, G. R. L.; Poulsen, S.-A.; Sanders, J. K. M. Molecular Evolution: Dynamic Combinatorial Libraries, Autocatalytic Networks, and the Quest for Molecular Function. Curr. Opin. Chem. Biol. 2000, 4, 270-279.

4. Ramström, O.; Lehn, J.-M. In Situ Generation and Screening of a Dynamic Combinatorial Carbohydrate Library against Concanavalin A. Chem. BioChem. 2000, 1, 41-48.

5. Ramström, O.; Lohmann, S.; Bunyapaiboonsri, T.; Lehn, J.-M. Dynamic Combinatorial Carbohydrate Libraries: Probing the Binding Site of the Concanavalin A Lectin. Chem. Eur. J. 2004, 10, 1711-1715.

6. Bunyapaiboonsri, T.; Ramström, O.; Lohmann, S.; Lehn, J.-M.; Peng, L.; Goeldner, M. Dynamic Deconvolution of a Pre-equilibrated Dynamic Combinatorial Library of Acetylcholinesterase Inhibitors. Chem. BioChem. 2001, 2, 438-444

7. Hochgürtel, M.; Kroth, H.; Piecha, D.; Hofmann, M. W.; Nicolau, C.; Krause, S.; Schaaf, O.; Sonnenmoser, G.; Eliseev, A. V. Target-Induced Formation of Neuraminidase Inhibitors from in Vitro Virtual Combinatorial Libraries. Proc. Natl. Acad. Sci. U.S.A. 2002, 99, 3382-3387.

8. Hochgürtel, M.; Biesinger, R.; Kroth, H.; Piecha, D.; Hofmann, M. W.; Krause, S.; Schaaf, O.; Nicolau, C.; Eliseev, A. V. Ketones as Building Blocks for Dynamic Combinatorial Libraries: Highly Active Neuraminidase Inhibitors Generated via Selection Pressure of the Biological Target. J. Med. Chem. 2003, 46, 356-358.

9. Huc, I.; Lehn, J.-M. Virtual Combinatorial Libraries: Dynamic Generation of Molecular and Supramolecular Diversity by Self-Assembly. Proc. Natl. Acad. Sci. U.S.A. 1997, 94, 2106-2110.

10. (a) Nguyen, R.; Huc, I. Using an Enzyme's Active Site to Template Inhibitors. Angew. Chem. 2001, 113, 1824-1826; (b) Angew. Chem. Int. Ed. 2001, 40, 1774-1776.

11. Cheeseman, J. D.; Corbett, A. D.; Shu, R.; Croteau, J.; Gleason, J. L.; Kazlauskas, R. J. Amplification of Screening Sensitivity Through Selective Destruction: Theory and Screening of a Library of Carbonic Anhydrase Inhibitors. J. Am. Chem. Soc. 2002, 124, 5692-5701.

12. (a) Corbett, A. D.; Cheeseman, J. D.; Kazlauskas, R. J.; Gleason, J. L. Pseudodynamic Combinatorial Libraries: A Receptor-Assisted Approach for Drug Discovery. Angew. Chem. 2004, 116, 2486-2490; (b) Angew. Chem. Int. Ed. 2004, 43, 2432-2436.

13. Bunyapaiboonsri, T.; Ramström, H.; Ramström, O.; Haiech, J.; Lehn, J. -M. Generation of Bis-Cationic Heterocyclic Inhibitors of Bacillus subtilis HPr Kinase/Phosphatase from a Ditopic Dynamic Combinatorial Library. J. Med. Chem. 2003, 46, 5803-5811.

14. (a) Zameo, S.; Vauzeilles, B.; Beau, J.-M. Dynamic Combinatorial Chemistry: Lysozyme Selects an Aromatic Motif That Mimics a Carbohydrate Residue. Angew. Chem. 2005, 117, 987-991; (b) Angew. Chem. Int. Ed. 2005, 44, 965-969.

15. Hong, L.; Williams, P.; Micklefield, J.; Gardiner, J. M.; Stephens, G. A Dynamic Combinatorial Screen for Novel Imine Reductase Activity. Tetrahedron 2004, 60, 753-758.

16. (a) Larsson, R.; Pei, Z.; Ramström, O. Catalytic Self-Screening of Cholinesterase Substrates from a Dynamic Combinatorial Thioester Library. Angew. Chem. 2004, 116, 3802-3804; (b) Angew. Chem. Int. Ed. 2004, 43, 3716-3718.

17. Hotchkiss, T.; Kramer, H. B.; Doores, K. J.; Gamblin, D. P.; Oldham, N. J.; Davis, B. G. Ligand Amplification in a Dynamic Combinatorial Glycopeptide Library. Chem. Commun. 2005, 4262-4266.

18. Jiang, Y. L.; Krosky, D. J.; Seiple, L.; Stivers, J. T. Uracil-Directed Ligand Tethering: An Efficient Strategy for Uracil DNA Glycosylase (UNG) Inhibitor Development. J. Am. Chem. Soc. 2005, 127, 17412-17420.

19. (a) Congreve, M. S.; Davis, D. J.; Devine, L.; Granata, C.; O'Reilly, M.; Wyatt, P. G.; Jhoti, H. Detection of Ligands from a Dynamic Combinatorial Library by X-ray Crystallography. Angew. Chem. 2004, 115, 46174620; (b)Angew. Chem. Int. Ed. 2003, 42, 4479-4482.

20. Poulsen, S.-A.; Bornaghi, L. F. Fragment-Based Drug Discovery of Carbonic Anhydrase II Inhibitors by Dynamic Combinatorial Chemistry Utilizing Alkene Cross Metathesis. Bioorg. Med. Chem., in press.

21. Weber, L. In Vitro Combinatorial Chemistry to Create Drug Candidates. Drug. Discov. Today: Technologies 2004, 1, 261-267.

22. Triolo, A.; Altamura, M.; Cardinali, F.; Sisto, A.; Maggi, C. A. Mass Spectrometry and Combinatorial Chemistry: A Short Outline. J. Mass Spectrom. 2001, 36, 1249-1259.

23. Loo, J. A. Studying Noncovalent Protein Complexes by Electrospray Ionization Mass Spectrometry. Mass Spectrom. Rev. 1997, 16, 1-23, and references therein.
24. Smith, R. D.; Bruce, J. E.; Wu, Q.; Lei, P. New Mass Spectrometric Methods for the Study of Noncovalent Associations of Biopolymers. Chem. Soc. Rev. 1997, 26, 191-202, and references therein.

25. Cheng, X.; Chen, R.; Bruce, J. E.; Schwartz, B. L.; Anderson, G. A.; Hofstadler, S. A.; Gale, D. C.; Smith, R. D. Using Electrospray Ionization FTICR Mass Spectrometry to Study Competitive Binding of Inhibitors to Carbonic Anhydrase. J. Am. Chem. Soc. 1995, 117, 8859-8860.

26. Gao, J.; Cheng, X.; Chen, R.; Sigal, G. B. Bruce, J. E. Schwartz, B. L.; Hofstadler, S. A.; Anderson, G. A.; Smith, R. D.; Whitesides, G. M. Screening Derivatized Peptide Libraries for Tight Binding Inhibitors to Carbonic Anhydrase II by Electrospray Ionization-Mass Spectrometry. J. Med. Chem. 1996, 39, 1949-1955.

27. Loo, J. A. Holler, T. P. Foltin, S. K. McConnell, P. Banotai, C. A. Horne, N. M.; Mueller, W. T.; Stevenson, T. I.; Mack, D. P. Application of Electrospray Ionization Mass Spectrometry for Studying Human Immunodeficiency Virus Protein Complexes. Proteins: Struct. Funct. Genet. Suppl. 1998, 2, 28-37.

28. Griffey, R. H.;. Sannes-Lowery, K. A; Drader, J. J.; Mohan, V.; Swayze, E. E.; Hofstadler, S. A. Characterization of Low-Affinity Complexes Between RNA and Small Molecules Using Electrospray Ionization Mass Spectrometry. J. Am. Chem. Soc. 2000, 122, 9933-9938.

29. Kruppa, G.; Schnier, P. D.; Tabei, K.: Van Orden, S. Siegel, M. M. Multiple Ion Isolation Applications in FT-ICR MS: Exact-Mass MS ${ }^{n}$ Internal Calibration and Purification/Interrogation of Protein-Drug Complexes. Anal. Chem. 2002, 74, 3877-3886.

30. Wigger, M. Eyler, J. R.; Benner, S. A.; Li, W.; Marshall, A. G. Fourier Transform-Ion Cyclotron Resonance Mass Spectrometric Resolution, Identification, and Screening of Noncovalent Complexes of Hck Src Homology 2 Domain Receptor and Ligands from a 324-Member Peptide Combinatorial Library. J. Am. Soc. Mass Spectrom. 2002, 13, 1162-1169.

31. Wang, W.; Kitova, E. N.; Klassen, J. S. Influence of Solution and Gas Phase Processes on Protein-Carbohydrate Binding Affinities Determined by Nanoelectrospray Fourier Transform Ion Cyclotron Resonance Mass Spectrometry. Anal. Chem. 2003, 75, 4945-4955.

32. De Vriendt, K.; Sandra, K.; Desmet, T.; Nerinckx, W.; Van Beeumen, J. Devreese, B. Evaluation of Automated Nano-Electrospray Mass Spectrometry in the Determination of Noncovalent Protein-Ligand Complexes. Rapid Commun. Mass Spectrom. 2004, 18, 3061-3067.

33. Tjernberg, A.; Carnö, S.; Oliv, F.; Benkestock, K.; Edlund, P.-O.; Griffiths, W. J.; Hallén, D. Determination of Dissociation Constants for Protein-Ligand Complexes by Electrospray Ionization Mass Spectrometry. Anal. Chem. 2004, 76, 4325-4331.

34. Quinton, L.; Le Caer, J.-P.; Phan, G.; Ligny-Lemaire, C.; BourdaisJomaron, J.; Ducancel, F.; Chamot-Rooke, J. Characterization of Toxins within Crude Venoms by Combined Use of Fourier Transform Mass Spectrometry and Cloning. Anal. Chem. 2005, 77, 6630-6639.

35. Poulsen, S.-A.; Davis, R. A.; Keys, T. G. Screening a Natural ProductBased Combinatorial Library using FTICR Mass Spectrometry. Bioorg. Med. Chem. 2006, 14, 510-515.

36. Scozzafava, A.; Owa, T.; Mastrolorenzo, A.; Supuran, C. T. Anticancer and Antiviral Sulfonamides. Curr. Med. Chem. 2003, 10, 925-953.

37. Pastorekova, S.; Casini., A; Scozzafava, A.; Vullo, D.; Pastorek, J.; Supuran, C. T. Carbonic Anhydrase Inhibitors: The First Selective, Membrane-Impermeant Inhibitors Targeting the Tumor-Associated Isozyme IX. Bioorg. Med. Chem. Lett. 2004, 14, 869-873.

38. Cousins, G. R. L.; Poulsen, S.-A.; Sanders, J. K. M. Dynamic Combinatorial Libraries of Pseudo-Peptide Hydrazone Macrocycles. Chem. Commun. 1999, 1575-1576.

39. Nguyen, R.; Huc, I. Optimizing the Reversibility of Hydrazone Formation for Dynamic Combinatorial Chemistry. Chem. Commun. 2003, 942-943.

40. Scozzafava, A.; Supuran, C. T. Carbonic Anhydrase Inhibitors. Curr. Med. Chem. Imun. Endoc. Metab. Agents 2001, 1, 61-97.

41. Pastorekova, S.; Parkkila, S.; Pastorek, J.; Supuran, C. T. Carbonic Anhydrases: Current State of the Art Therapeutic Applications and Future Prospects. J. Enz. Inhib. Med. Chem. 2004, 19, 199-229.

42. Winum, J.-Y.; Dogne, J.-M.; Casini, A.; de Leval, X.; Montero, J.-L.; Scozzafava, A.; Vullo, D.; Innocenti, A.; Supuran, C. T. Carbonic Anhydrase Inhibitors: Synthesis and Inhibition of Cytosolic/Membrane-Associated Carbonic Anhydrase Isozymes I, II, and IX with Sulfonamides Incorporating Hydrazino Moieties. J. Med. Chem. 2005, 48, 2121-2125.

43. Chen, R. F.; Kernohan, J. C. Combination of Bovine Carbonic Anhydrase with a Fluorescent Sulfonamide. J. Biol. Chem. 1967, 242, 5813-5823.

44. Sigal, G. B.; Whitesides, G. M. Benzenesulfonamide-Peptide Conjugates as Probes for Secondary Binding Sites Near the Active Site of Carbonic Anhydrase. Bioorg. Med. Chem. Lett. 1996, 6, 559-564.

45. Poulsen, S.-A.; Bornaghi, L. F.; Healy, P. C. Synthesis and StructureActivity Relationships of Novel Benzene Sulfonamides with Potent Binding Affinity for Bovine Carbonic Anhydrase II. Bioorg. Med. Chem. Lett. 2005, 24, 5429-5433. 